\title{
THE EFFECT OF INCENTIVES AND LEADERSHIP STYLES ON CREATIVE PERFORMANCE
}

\author{
Sariyatul Ilyana ${ }^{1 *}$, Mahfud Sholihin ${ }^{1}$ \\ ${ }^{1}$ Department of Accounting, Faculty of Economics and Business, Universitas Gadjah Mada, \\ Yogyakarta, 55281, Indonesia
}

\begin{tabular}{|c|c|}
\hline ABSTRACT & ARTICLE INFO \\
\hline 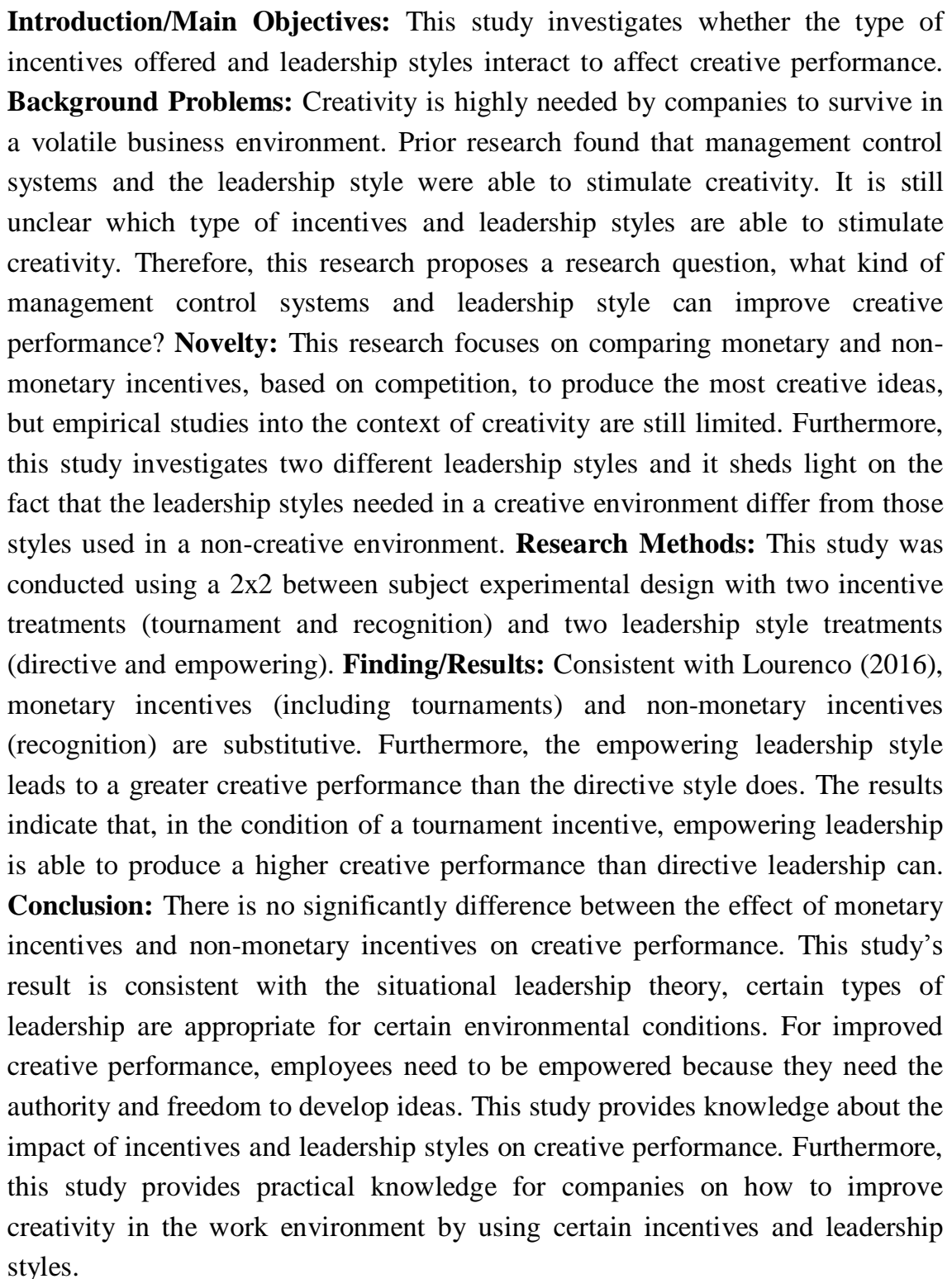 & $\begin{array}{l}\text { Article information: } \\
\text { Received: September 19, } \\
\text { 2020. Received in revised } \\
\text { version: November 16, } \\
\text { 2020. Accepted: } \\
\text { November 23, 2020. } \\
\text { Keywords: } \\
\text { creative performance, } \\
\text { incentives, leadership } \\
\text { styles }\end{array}$ \\
\hline
\end{tabular}

\footnotetext{
${ }^{1}$ Corresponding Author at Department of Accounting, Faculty of Economics and Business, Universitas Gadjah Mada, Jalan Socio Humaniora No. 1, Yogyakarta 55281, Indonesia.

E-mail address: sariyatul.ilyana@mail.ugm.ac.id (author\#1), mahfud@ugm.ac.id (author\#2)
} 


\section{INTRODUCTION}

Nowadays industry is facing a volatile environment. The level of market competition is enormous and technology is rapidly developing. Employees' creativity is vital for companies to enhance their organizational competitiveness to face the dynamic environment (Gong, Zhou, \& Chang, 2013). However, the problem for business organizations is that not all individuals are creative, or motivated to be creative (Klotz, Wheeler, Halbesleben, Brock, \& Buckley, 2012). Therefore, companies need to facilitate organizational systems that encourage the employees to perform creatively.

Management control systems (MCS) and leadership have an important role in stimulating creativity in the work environment (Speckbacher, 2017). MCS affect the perceived conditions, constraints, and project goals in generating creative ideas. Therefore, MCS work in shaping, framing, and defining problems that require creative solutions (Speckbacher, 2017). On the other hand, leaders create situational contexts and conditions in which subordinates are involved in creative efforts to achieve organizational goals (Jung, 2001). Incentives are one of the MCS used to improve performance (Bonner \& Sprinkle, 2002). Empirical studies show that incentives and leadership are effective in enhancing employee performance (Chen, Lin, Lin, \& Iii, 2012), and the best way to engage employees in the organizational goals (Benazir \& Iqbal, 2015). However, there are many kinds of incentives and leadership. There is no clear answer for which type of incentives and leadership are able to improve performance in the context of creativity. This drives us to investigate what types of incentives and leadership can improve people's creative performance.

There are several types of incentives, they are monetary incentives, recognition, and feedback (Stajkovic \& Luthans, 2001). Recent research showed that monetary incentives and recognition are substitutive for improving performance, whereas feedback has no effect on performance (Lourenco, 2016). This provides evidence that in the context of employment relations, recognition is as effective as monetary incentives. One type of monetary incentive is the tournament incentive. Both tournament and recognition use a system of competition (Cadsby, Engle-warnick, Fang, \& Song, 2015). However, the level of effectiveness from using these kinds of incentives to improve creative performance is unknown. Most studies have examined the comparison of two types of monetary incentives (Charness \& Grieco, 2018; Chen, Williamson, \& Zhou, 2012; Kachelmeier, Reichert, \& Williamson, 2008) or a comparison of piece-rate incentives and recognition (Huo, 2015) for improving creative performance. Therefore, this study aims to investigate the effect of tournament incentives and recognition on creative performance.

Beside incentives, Amabile et al. (2004) emphasized the importance of leadership in encouraging individual creativity. The study conducted by Amabile et al. (2004) showed that a leader who interacts daily with his/her subordinates was able to direct and influence their perceptions, feelings, and daily performance, which in turn affects the overall creativity of their work. Martin, Liao, and Campbell (2013) stated that there are two types of leadership styles, namely directive and empowering leadership. Some previous studies have found that directive leadership is more effective in stimulating performance (Lorinkova, Pearsall, \& Sims, 2013; Yun, Faraj, \& Sims, 2005). This is because the directive leader focuses on the employee's task effort by giving specific and relevant directions for the task, setting clear rules for behavior (Lorinkova et al., 2013), and monitoring the progress of the work (Yun et al., 
2005). Therefore, employee performance can improve. However, in the context that requires employees to think creatively, autonomy and appreciation is needed for generating new ideas (Alge, Ballinger, Tangirala, \& Oakley, 2006), and this relates to the empowering leadership style. This issue encourages us to investigate whether empowering leadership is able to improve creative performance, compared to directive leadership.

The interrelation of MCS, leadership, and creativity is important to explore. Thus far, the interrelation of leadership and MCS in influencing creative performance has received little attention (Speckbacher, 2017). Therefore, this study will examine the interaction of incentives as part of the MCS and leadership style for encouraging creative performance.

This research makes several contributions to the existing literature. First, this research contributes by focusing on the comparison between monetary and non-monetary incentives for influencing creative performance. The novel feature of this study is that it compares monetary and non-monetary incentives, based on competition, to find which produces the most creative ideas. Most of the previous studies have examined different types of monetary incentives (Charness \& Grieco, 2018; Chen, Williamson, et al., 2012; Erat \& Gneezy, 2016), and piece-rate incentives and recognition (Lourenco, 2016). Therefore, this current research enriches the literature by investigating both monetary and non-monetary incentives in creative performance's context. Second, this research sheds light on the different leadership styles that have different effects on creative performance. Empowering leadership produces a better creative performance through a process of providing autonomy, freedom of thought, and a work environment that is not rigid. Third, this research validates the findings of case studies conducted by Davila and Ditillo (2017) and Cools, Stouthuysen, and Abbeele (2017) regarding the interrelations between MCS, leadership, and creative performance using experimental studies.

The rest of the paper is organized as follows. Section 2 has the literature review and hypotheses development. This will be followed by the research method in Section 3. Findings and discussions are presented in Section 4. The paper ends with conclusions, limitations, and suggestion for future research.

\section{LITERATURE REVIEW}

\section{Creative Performance}

Creative performance is the development of products, ideas, or solutions to new problems that form the basis of innovation by individuals, organizations, and society (Hennessey \& Amabile, 2010; Shalley \& Gilson, 2004). In the psychology literature, ideas are classified as creative if they are original, innovative, and can be implemented within a reasonable budget (Amabile, 1996). The employees' work environment has an impact on their creativity (Mclean, 2005). There are six supporting factors and two impediment factors for a creative work environment (Amabile, Conti, Coon, Lazenby, \& Herron, 1996). The supporting factors include: a) organizational encouragement, b) supervisory encouragement, c) work group support, d) freedom, e) sufficient resources, and f) challenges. The impediment factors include: a) workload pressure, and b) organizational impediments. Based on the background that has been described, we focus on organizational encouragement and supervisory encouragement.

\section{Creative Performance and Incentives}

The literature on creativity has documented the positive influence of motivational approaches on individual success, to reach originality in the 
creative tasks (Friedman \& Forster, 2001). This research applied the expectancy theory by Vroom (1964) to explain incentives and creative performance. Based on the expectancy theory, individuals maximize the expected satisfaction by achieving certain results. The expectancy theory identified three conditions that produce high levels of motivation to perform tasks, namely: 1) The existence of expectations or beliefs that greater effort will improve performance (expectancy). 2) There is trust in the performance measurement systems and performance-based rewards (instrumentality). 3) There is a relationship between the assignments given to individuals and the rewards (valence). The basic idea of the expectancy theory is based on a reinforcement perspective, which supports a utilitarian view of human nature and assumes that external reinforcement can strengthen behavioral dimensions, such as strength, duration, novelty, and variability (Skinner, 1938).

Gellner and Pull (2013) used the expectancy theory to provide evidence of whether tournament compensation systems, in a condition of employee heterogeneity, affect firm performance. Their results indicated that although tournament compensation is more effective in homogeneous employee conditions, tournament compensation is still needed for groups of employees who have high effort-performance expectations; they are called the "threshold group." They also found that the relationship between compensation and performance was an inverted u-shape. The extreme (low and high) groups have less motivation to increase their efforts than the threshold group has. This perspective explains that individuals who have expectations of the results to be obtained tend to expend a great deal of effort to achieve the maximum results. In the creativity context, Eisenberger and Cameron (1998) stated that extrinsic rewards direct empoloyees' efforts in the desired direction and result in behavioral changes toward creativity when the incentives given depend on creative performance.

There are two types of incentives examined in this study, namely tournament incentives and recognition. The difference between tournament incentives and recognition is that tournament incentives are given in the form of money, while recognition is a non-monetary reward. Mehta, Dahl, and $\mathrm{Zu}$ (2017) explained that monetary incentives were able to increase individuals' motivation to enhance creative tasks, while recognition is more motivated by normative goals. In this instance, normative goals are based on social and task parameters. By using monetary-based incentives, individuals tend to propose a creative solution for a task that is more original than the solution from those individuals who have a normative focus. Therefore, the creative performance is expected to be greater from individuals who are offered money rather than recognition. Formally, we propose the first hypothesis:

H1: Individuals who get tournament incentives will produce a higher creative performance than individuals who get recognition incentives.

\section{Leadership Styles and Creative Performance}

Amabile (1996) found that there is a positive relationship between organizational environments that offer organizational encouragement and work-group support for employees' innovation and creativity. The situational leadership theory is a practical tool for managers to determine what leadership styles need to be applied when dealing with different situations. This theory is based on the principle that the relative benefits of each leadership style depend on the competence, maturity, or readiness of the followers (Thompson \& Vecchio, 2009). A 
pragmatic view of the situational leadership theory was later developed by Sims, Faraj, and Yun (2009), who provided a fundamental assumption that certain types of leadership tend to be effective in certain situations.

In this study, the two leadership styles tested are the directive leadership style and the empowering leadership style. According to Lorinkova et al. (2013), directive leadership is associated with the strength of the leader's position and is characterized by behavior aimed at actively structuring the work of subordinates, by providing them with clear directions and expectations related to their compliance with the instructions. On the other hand, empowering leadership tends to encourage the participation of subordinates by contributing ideas, encouraging optimal actions, and giving responsibility for each performance produced.

A study conducted by Kanter (1982) found that directive leaders encourage the innovation process by controlling, monitoring, instructing, and providing a hierarchical influence. However, directive leadership tends to involve limits and controls over the employees. In fact, creativity is produced from the belief of individuals that they have the freedom to produce new ideas, and the belief that their ideas will be valued (Alge et al., 2006). Empirical studies provide support for this argument, and several studies have found that employees are more creative when they feel more empowered and that they have the best choice of ways to carry out their assigned tasks and work (Alge et al., 2006; Mubarak \& Noor, 2018; Zhang \& Bartol, 2010). Likewise, Shalley Zhou, and Oldham (2004) linked autonomy with creative behavior in their review of the creativity literature. The overall implication of this study is that to stimulate creativity, the work environment must support the perception of empowerment. Based on this explanation, therefore we propose a second hypothesis:
$\mathrm{H} 2$ : Individuals who are empowered by their leader will produce a greater creative performance than individuals who are directed by their leader.

\section{Incentives, Leadership Style, and Creative Performance}

Empowerment practices and incentives are seen as investments in human resources that give employees unique knowledge, skills and abilities to achieve organizational goals, so as to increase results at the organizational level, and increase competitiveness in the market (Bowen \& Ostroff, 2004; Takeuchi, Lepak, Takeuchi, Lepak, \& Wang, 2007). The development of an incentive and empowerment climate can be done together, so it is important to determine whether the synergy of the application of leadership and incentives has an influence on employee performance (Kuenzi \& Schminke, 2009). The application of empowerment and incentives to encourage creative performance can be explained through the organizational equilibrium theory. In this theory, researchers investigate conditions in which an organization can produce stimuli for its employees to provide a level of performance that is more than, or equal to, the contribution made by the company, which in turn is directed to finding conditions that are useful for the survival of the organization (Takatsu, 1984). A study by Hammerman and Mohnen (2014) showed that giving monetary prizes in a competition can produce a better performance than offering non-monetary prizes can. That is, tournament monetary incentives are more attractive to individuals than non-monetary ones. The company's efforts to produce a high performance by its employees are in line with the higher expenses. Expenditure on higher costs is expected to obtain higher creative performances. 
However, individuals will be less motivated to undertake assignments if they are not empowered, so the incentives given have less effect on performance (Kim, Sutton, \& Gong, 2013). Naturally, companies expect that the costs incurred are not in vain and produce the expected output. The combination of performance-based incentive payments with empowerment gives employees the motivation to achieve higher goals and contribute to the overall company performance. This happens because individuals have the decision-making authority to make plans to achieve goals, and individuals will experience greater satisfaction when the results achieved are because of the actions they initiated (Kim et al., 2013). Therefore, by applying monetary incentives and empowerment, individuals will be motivated to pursue new ideas and produce a more creative performance. Based on these explanations, the third hypothesis proposed by this study is:

H3: Under tournament incentive conditions, individuals who are empowered by their leader will produce a higher creative performance than individuals who are directed.

\section{METHOD, DATA, AND ANALYSIS}

\section{Experimental Design}

This study is a laboratorium experiment which uses an experimental procedure with a $2 \times 2$ between subject design. The experiment is designed using two treatments in two different conditions, i.e. the treatment of incentives (tournament vs recognition) and leadership styles (directive leadership vs empowering leadership).

\section{Participants}

The participants in this study were undergraduate accounting students at a major university in Yogyakarta, Indonesia who have taken management accounting and entrepreneurship courses. The experimental assignment was to develop a business idea. Previous research used the same experimental assignment and found that students could become participants in the creative performance research (Chen et al., 2012). This is because students have the knowledge and abilities needed for the development of business ideas. Both courses should be have been taken by the participants. Management accounting courses provide knowledge about companies' management control systems so that the participants have more understanding of the given assignment; while the entrepreneurship course provides knowledge about business planning, both the processes for identifying opportunities and developing a business. This knowledge is important and helps the participants to develop their business ideas. Before performing the experiment, we conducted a pilot test with undergraduate accounting students at another major university in Yogyakarta, who also have taken both courses as the participants.

Table 1. 2 x 2 Between Subject Experimental Design

\begin{tabular}{ccc}
\hline & \multicolumn{2}{c}{ Leadership Style } \\
\cline { 2 - 3 } Treatments & $\begin{array}{c}\text { Directive } \\
\text { leadership }\end{array}$ & $\begin{array}{c}\text { Empowering } \\
\text { leadership }\end{array}$ \\
\hline Incentives & Tournament & 2 \\
Recognition & 3 & 4 \\
\hline Note: & 1 & treatment 1 = tournament incentives collaborate with \\
directive leadership, treatment 2 = tournament \\
incentives collaborate with empowering leadership, \\
treatment 3 = recognition incentives collaborate with \\
directive leadership, treatment 4 = recognition \\
incentives collaborate with empowering leadership
\end{tabular}

\section{Variables}

\subsection{Manipulated/Independent Variables}

\subsubsection{Incentives}

Two types of incentives were used in this experiment: tournament incentives and recognition incentives. The monetary incentive system 
was adopted from Chen, Williamson and Zhou (2012) while the recognition system was adopted from Kosfeld and Neckermann's research (2010). In a tournament incentive scheme, if one participant becomes the most creative among all the other participants, that participant will get some money; the others do not get anything. For the recognition incentive, the best performer will be given the title of "most creative employee."

\subsubsection{Leadership Style}

The two types of leadership styles used in this experiment were directive leadership and empowering leadership. The instrument was developed using the leader behavior utterance phrase from Lorinkova et al., (2013).

\subsection{Outcome/Dependent Variables}

The dependent variable in this study was creative performance. The task to test creativity was modified from Chen, Williamson, and Zhou (2012). In that instrument, the participants developed a proposal for the creative use of empty buildings around a campus, and set a budget to be submitted for the work. The measurement of creative performance used the judgment of three participants who were chosen as the panelists. The panelists determined the best creative performance. In this study, we modified the task as follows. The participants were given a case regarding a building that had not been used for five years. They were asked to develop a proposal or idea for how they could use the unproductive building and estimate the necessary funding requirements. The ideas that were developed were then evaluated by three independent panelists who are experts in the field of developing business ideas, including an entrepreneurship lecturer, a management accounting professor, and a business practitioner. Assessments were given, ranging from 0 to 10 (0 = lowest creativity, $10=$ highest creativity).
Such measurements have been used before by Chen, Williamson, and Zhou (2012) for measuring the creative performance of individuals and groups. The participants who had the highest total scores were told they would receive incentives.

\section{Experimental Procedures}

This experiment was conducted during October 2019. The experiment was carried out through several procedures as follows:

1. Participants entered the classroom, as an experimental laboratory, and turn off their communication equipment for the duration of the experiment.

2. The experimenters divided the participants randomly into four groups. The groups were tournament-directive, tournament-empowering, recognition-directive, and recognitionempowering groups.

3. Participants were given a package of experimental instruments consisting of six parts, namely 1) rules, 2) company description, 3) problems, explanation of creative assignments, and incentive schemes, 4) leadership style, 5) work sheets for creative assignments, 6) demographic information.

4. At the pre-assignment stage, each participant received the following information:

a. Rules for the experiment

b. Company description

c. Problems encountered

d. Explanation of the creative task to be performed

e. Explanation of incentives provided. For the tournament incentive group, the participants who succeeded in generating the best ideas were to receive IDR $100,000 .^{2}$ On the other hand, for the

\footnotetext{
${ }^{2}$ On the date of experiment, USD1 was equal to IDR 14,138
} 
recognition incentive groups, the participants who succeeded in generating the best ideas would be awarded the title of "creative employees," with a certificate stating this, and it would be announced to the participants

f. Participants filled out the manipulation checks of the incentives

g. Participants were given information about the manager's leadership style.

5. Participants were given a treatment of leadership styles that were adopted and modified from the phrase leadership style by Lorinkova et al. (2013).

6. Participants performed creative tasks by developing proposals for ideas for an unproductive building's utilization for 30 minutes. $^{3}$

7. Participants filled in their demographic data.

8. Debriefing. Experimenter provided information about the purpose of the experiment that had been undertaken by the research subjects. The experimenter also explained the hypotheses proposed by the study and if there were respondents who wanted the results of the research, then the researcher would be pleased to give it to them (Cooper \& Schindler, 2014).

\section{RESULT AND DISCUSSION}

\section{Results}

As previously mentioned, before conducting the experiment, we performed a pilot test. Participants in this pilot test were 30 undergraduate students who had taken management accounting and entrepreneurship courses, just like the experiment's participants. In this pilot test, we examined two types of incentives to find out whether the incentives were comparable and able to motivate the participants. We conducted a test

\footnotetext{
${ }^{3}$ The time is based on the pilot study
}

of individuals' motivation for tournament incentives and recognition incentives by using independent sample t-tests. Motivation was measured on a scale of 1 to 10 ( 1 = highly unmotivated, $10=$ highly motivated). The difference in motivation showed the value of $F=0.019$; $p$ > 0.579 , which meant that there was no significant difference between tournament incentives and recognition incentives for motivating the participants. It meant that tournament incentives with a nominal value of IDR100,000 and recognition incentives, such as the most creative employee awards, were comparable.

For the leadership style, we ensured the accuracy of the treatment of the leadership style used by testing the tendency of the leader to direct, or not, on a scale of 1 to $10(1=$ no direction at all, $10=$ very directive). The directive leadership style tends to direct while the empowering leadership style tends not to direct. The test was carried out using an independent sample t-test. The result was an average tendency toward the participants who were treated with a directed leadership style score of 8.44, and an empowering leadership style score of 5.83. The difference in the directive tendency of both leadership styles showed a value of $\mathrm{F}=$ $1.348, \mathrm{p}<0.05$, which means that there was a significant difference between the directive and empowering leadership styles.

The overall results of the pilot test showed that the incentive instruments, leadership styles, and creative performance were clearly understood by the participants, and were valid.

The participants in the experiment were 92 undergraduate accounting students at Universitas Ahmad Dahlan who had taken management accounting and entrepreneurship courses. Assignments and group divisions were carried out randomly. After going through a manipulation check, which only 63 students passed, the data were further processed. 
As previously mentioned, the creative performance of participants was assessed by three experts consisting of: a management accounting professor, a lecturer on entrepreneurship, and a business practitioner. The results of the assessment of creative performance were tested for reliability using the Intraclass Coefficient Correlation (ICC). The results showed the Cronbach's alpha value was 0.690. It meant the instrument was reliable. Table 2 shows the results of the descriptive statistics for the creative performance.
We conducted a correlation analysis to test the correlation between the variables measured, using Spearman's correlation analysis, the results are presented in Table 3. Based on the test results, there was a positive correlation between incentives and the style of leadership with creative performance, but this was not significant.

We used two-way ANOVA to test the hypotheses. This study predicted that there would be an influence from incentives and leadership styles on creative performance (Table 4).

Table 2. Descriptive statistics

\begin{tabular}{cccccccccc}
\hline \multirow{2}{*}{ Incentives } & \multicolumn{4}{c}{ Leadership style } & \multicolumn{3}{c}{ Total } \\
\cline { 2 - 7 } & \multicolumn{3}{c}{ Directive leadership } & \multicolumn{2}{c}{ Empowering leadership } & & \\
\cline { 2 - 7 } & Mean & N & SD & Mean & N & SD & Mean & N & SD \\
\hline Tournament & 6.376 & 14 & 0.723 & 6.664 & 15 & 0.705 & 6.525 & 29 & 0.716 \\
Recognition & 6.511 & 19 & 0.646 & 6.984 & 15 & 0.89 & 6.719 & 34 & 0.788 \\
Total & 6.453 & 33 & 0.672 & 6.824 & 30 & 0.806 & 6.632 & 63 & 0.756 \\
\hline
\end{tabular}

Note: $\mathrm{N}=$ total of participants that passed the manipulation checks

Table 3. Correlation matrix

\begin{tabular}{lccc}
\hline \multicolumn{1}{c}{ Variables } & 1 & 2 & 3 \\
\hline Creative performance & 1 & & \\
Incentives & 0.104 & 1 & \\
Leadership styles & 0.234 & -0.076 & 1 \\
\hline Note: the response was from 63 participants.
\end{tabular}

Note: the response was from 63 participants.

Table 4. Two-way ANOVA test results

Dependent Variable: Creative Performance

\begin{tabular}{lllll}
\hline \multicolumn{1}{c}{ Sources } & Df & Mean square & \multicolumn{1}{c}{ F } & Sig \\
\hline Corrected Model & 3 & 1.025 & 1.868 & 0.145 \\
Intercept & 1 & $2,735.65$ & $4,985.07$ & 0.000 \\
Incentives & 1 & 0.802 & 1.461 & 0.232 \\
Leadership Styles & 1 & 2.257 & 4.113 & $0.047^{*}$ \\
Incentives * Leadership Styles & 1 & 0.134 & 0.244 & 0.623 \\
Error & 59 & 0.549 & & \\
Total & 63 & & & \\
Corrected Total & 62 & & & \\
\hline$R$ Squared = 0.087 (Adjusted $R$ Squared=0,040) & & \\
Note: dependent variable = creative performance; independent variables = 1) incentives, 2) leadership style \\
* indicates significance at 5\%
\end{tabular}




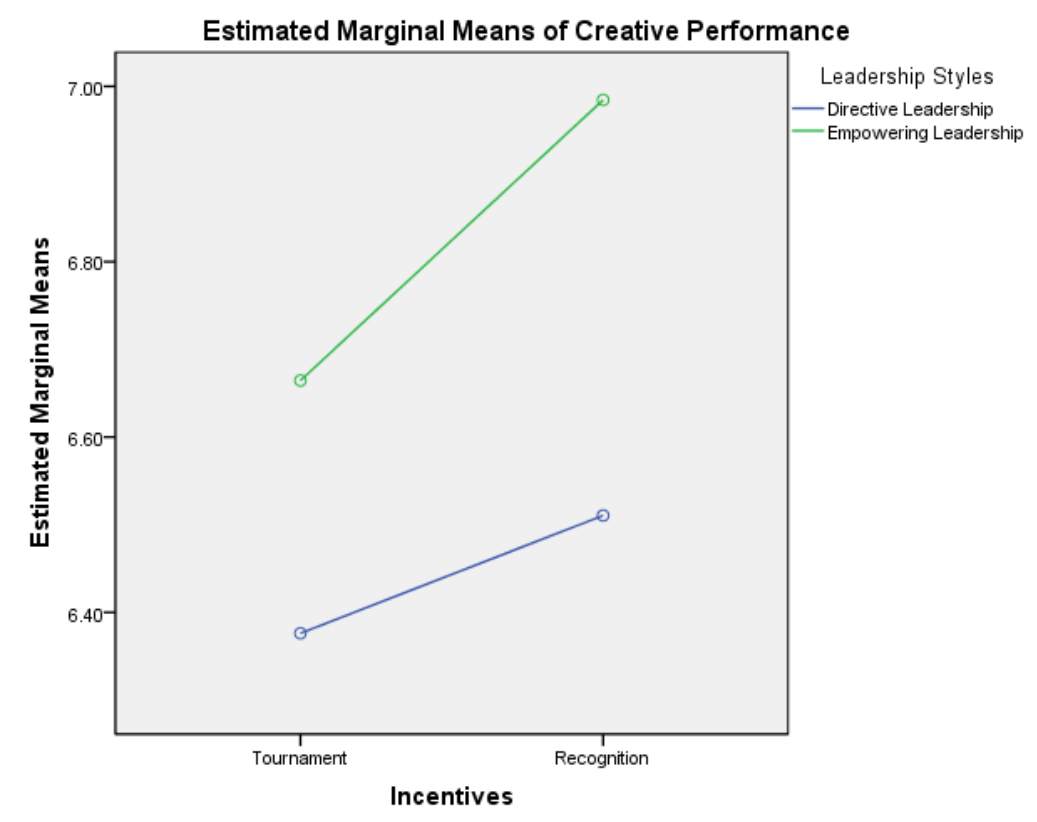

Figure 1. Plots of Incentive Interactions and Leadership Styles

Based on the results of the two-way ANOVA, incentives did not significantly influence creative performance. This was indicated by an $\mathrm{F}$ value of $1.461 ; \mathrm{p}>0.232$. On the other hand, the leadership style had a significant effect on creative performance, as indicated by an $\mathrm{F}$ value of $4.113 ; \mathrm{p}<0.047$. The interaction between incentives and leadership styles for influencing creative performance was not significant. This was indicated by an $\mathrm{F}$ value of $0.244 ; p>0.623$. The following is a plot of the interaction between incentives and leadership styles on creative performance.

Hypothesis 1 predicted that individuals who receive tournament incentives produce a higher creative performance than individuals who get recognition incentives. Table 2 shows that individuals who had tournament incentives produced an average creative performance score of 6.525, while individuals who received recognition incentives produced an average creative performance score of 6.719. However, based on Table 3, the different types of incentives for creative performance are not significant, as $p>0.232$. Thus, based on the results of the statistical testing of $\mathrm{H} 1$, it is not supported.

Hypothesis 2 predicted that individuals who are treated with an empowering leadership style will produce a higher creative performance than individuals who are treated with a directive leadership style. Based on Table 2, the individuals who received an empowered leadership style treatment produced a creative performance score of 6.824 , while the individuals who had a directive leadership style treatment produced a creative performance score of 6.453. Table 3 shows the difference is statistically significant at $\mathrm{p}=0.047$. These results indicate that the leadership style affects creative performance. Thus, H2 is supported.

Hypothesis 3 predicted that under tournament incentive conditions, individuals who are treated with an empowered leadership style will produce a higher creative performance than individuals who get treated with a directive leadership style. We conducted a one-way ANOVA test to see the differences in the results under tournament incentive conditions. 
Table 5. One-way ANOVA test results

Dependent Variable: Creative Performance

\begin{tabular}{llllc}
\hline Variable & Df & $\begin{array}{c}\text { Mean } \\
\text { square }\end{array}$ & F & $\begin{array}{c}\text { Signi- } \\
\text { ficance }\end{array}$ \\
\hline Leadership Style & 1 & 0.602 & 1.180 & 0.287 \\
\hline Note: in tournament incentive condition
\end{tabular}

Based on Table 2, in tournament incentive conditions, individuals who had the empowered leadership style treatment produced an average creative performance score of 6.664 while the individuals who received the directive leadership style treatment produced an average creative performance score of 6.376. The test results in Table 5 show that the significance level of the average difference between the two $(p=0.287)$ is not significant. Therefore, $\mathrm{H3}$ is not supported.

\section{Discussion}

Hypothesis 1 predicted that tournament incentives can produce a higher creative performance than recognition incentives. However, based on the results of the statistical testing, there were no significant differences between tournament incentives and recognition for influencing creative performance. This was evidenced by the $F$ value of 1.461 , with $p=0.232$. The results of this study differ from the previous study by Mehta, Dahl, and Zhu (2017), it turns out that both monetary and non-monetary competition has little difference in affecting creative performance. However, the results of this study are in line with Lourenco's statement (2016) that monetary incentives (including tournament incentives) are substitutive with recognition incentives. Both are able to produce an extrinsic motivation for employees to perform better.

Incentives play a key role in generating motivation and become an important component in an organization's efforts to encourage creativity. The expectancy theory states that motivation is a product of the valence, expectations, and mediation of incentives (Vroom, 1964). Vroom's initial concept, which stated that money plays an important role in getting desired things, is a rational reason why individuals tend to choose money over recognition. However, the results of this study actually found that there was no significant difference between incentives in the form of money or recognition for influencing creative performance. We tested the comparability of both incentives for motivating the participants. Based on the test, there was no significantly difference between monetary incentives and recognition. This indicated that recognition has the ability to motivate participants, as well as monetary incentives. This caused no difference in the performance results between participants who were given monetary incentives or those given recognition.

The difference between monetary incentives (including tournaments) and recognition lies in the mechanism of motivation. Lourenco (2016) explained that monetary incentives use the tangible payoffs motivation mechanism while recognition incentives use a self-regulation motivation mechanism. Besides Lourenco (2016), Delfgaauw et al. (2013) also found the same research results. Delfgaauw et al. (2013) conducted a field experiment in a retail company in the Netherlands using a competition system for each store's sales achievements. This competition was held to get incentives in the form of non-monetary (recognition) and monetary rewards. In the study, there was no significant difference between the performance improvement of the groups given monetary and non-monetary incentives. The results of the study of Lourenco (2016) and Delfgaauw et al. (2013) support the results of this study; there is no significant difference between monetary and non-monetary incentives. This convinced us that, even in the creative context, the two types of 
monetary and non-monetary incentives did not differ significantly in their ability to improve creative performance.

Furthermore, Hypothesis 2 predicted that individuals who are treated with an empowering leadership style are able to produce a higher creative performance than a directive leadership style can. The results showed that the empowering leadership style was significantly able to produce a higher creative performance than the directive leadership style. Based on the situational leadership theory, certain leadership styles will be effective in certain conditions. In the context of creative performance, empowering leadership is more effective in producing a higher creative performance. Many companies are creative and commercially successful, from Ferrari (Morse, 2006) to Google (Iyer \& Davenport, 2008) which shows that cultural and environmental factors are very important. A company that is successful with its creativity creates an environment where employees are free to be creative by utilizing the intrinsic motivation possessed by individuals (Klotz et al., 2012); this is in accordance with the concept of empowerment.

The position of the organization does not strongly influence the creation of ideas. Participation and autonomy are actually given to individuals in creative positions. The ideamaking function within an organization is separated from the idea-evaluation function and the communication channel that connects all the relevant units in the organization. The most important thing is that organizational leaders can adhere to a management philosophy rooted in the belief that employees are competent and can be creative in completing their assigned work functions (Klotz et al. 2012).

Hypothesis 3 predicted that under tournament incentive conditions, individuals who are treated with an empowering leadership style will produce a higher creative performance than individuals who are treated with a directive leadership style. Although the results of statistical testing are not significant, under conditions of tournament incentives and empowering leadership styles, individuals are able to produce a higher creative performance. This is in line with the organizational equilibrium theory that states that inducements in the form of incentives provided by the company will encourage the employees to make a greater contribution when the leaders of the company apply an empowering leadership style, rather than a directive leadership style.

\section{Supplementary Analysis}

We suspected that tournament incentive conditions and an empowering leadership style would produce the highest creative performance compared to the other conditions. However, this study's results actually show that recognition and an empowering leadership style are able to produce the highest creative performance. This prompted us to examine the differences in tournament incentives and recognition incentives under the condition of an empowering leadership style, using a one-way ANOVA analysis.

Table 6. One-way ANOVA Analysis Result Dependent Variable: Creative Performance

\begin{tabular}{lcccc}
\hline Variabel & Df & Mean square & F & Sig \\
\hline Incentives & 1 & 0.768 & 1.190 & 0.285 \\
\hline \multicolumn{5}{l}{ Note: In empowering leadership condition }
\end{tabular}

The test results in Table 6 show that there is no significant difference between tournament incentives and recognition under the empowering leadership style conditions. The results of this test are still consistent with the results of Lourenco's (2016) research on empowering leadership style conditions.

In addition, to ensure that the creative performance results were generated by the 
treatment given, the researcher conducted a preand post-test examination. We tested the creative performance before and after the treatments. We used a paired sample T-test to test the significance of the difference between the pre-test and post-test.

Table 7 shows that the participants produced an average creative performance score of 5.958 in the pre-test and 6.63 in the post-test. The results of the independent sample T-test show a significance value of 0.000 , which meant there was a significant difference between the pre-test and post-test. This explains that the treatment of incentives and leadership styles can improve the creative performance of individuals.

To provide an additional insight into the effect of incentives on creative performance, we examined the difference in the two conditions between the presence and absence of an incentive. This test was carried out using a paired sample T-test, which tests conditions when participants have not been and have been given incentives.

Based on the results shown in Table 8 , the two types of incentives are equally able to significantly increase people's creative perfor- mance. The increase in the average creative performance was higher for recognition incentives (0.703), while for tournament incentives it was 0.635 . This shows that although, in the twoway ANOVA test, incentives did not significantly influence things, in the pre-test and posttest testing the incentives were able to encourage the participants to do more creative tasks. Incentives are still needed to encourage employees to think more creatively in doing their work. However, the difference between the two types of incentives is not significant in influencing creative performance, because both are substitutive (Lourenco, 2016).

\section{CONCLUSION AND SUGGESTION}

This research provides experimental research results about the effect of incentives and leadership styles on creative performance. The results of the study showed that there is no significant difference between tournament incentives and recognition incentives for influencing creative performance. This is consistent with Lourenco's research (2016) that monetary incentives (including tournaments) and recognition are substitutive. Furthermore, this

Table 7. The results of the pre-test and post-test descriptive tests

\begin{tabular}{lcccccccc}
\hline Creative performance & Mean & $\mathrm{N}$ & SD & Std. Error & Mean difference & T & Df & Sig \\
\hline Pre-test & 5.958 & 63 & 0.709 & 0.089 & -0.672 & -6.843 & 62 & $0.000^{*}$ \\
Post-test & 6.630 & 63 & 0.756 & 0.095 & & & & \\
\hline
\end{tabular}

Note: $*$ indicate significance at $5 \%$

Table 8. Creative Performance in the Presence and Absence of Incentives

\begin{tabular}{lcc}
\hline & \multicolumn{2}{c}{ Incentives } \\
\cline { 2 - 3 } & Tournament & Recognition \\
\hline No incentives & 5.889 & 6.017 \\
Incentives & 6.525 & 6.719 \\
Mean difference & 0.635 & 0.703 \\
$t$ value & -4.556 & -5.044 \\
Sig. & $0.000^{*}$ & $0.000^{*}$ \\
\hline
\end{tabular}

Note: $*$ indicate significance at $5 \%$ 
study examines whether the empowering leadership style is able to produce a higher creative performance than the directive leadership style. The results of this study support this hypothesis. Consistent with the situational leadership theory, certain styles of leadership are appropriate for certain environmental conditions. In a creative environment, employees need to be empowered because then they have the authority and freedom to develop ideas. Recognition incentives and an empowering leadership style produce the highest creative performance.

The results of this study have several implications. Theoretically, this study provides knowledge about the impact of the relationship of incentives and leadership style on creative performance. First, tournament incentives and recognition incentives have the same ability to influence creative performance. That is, the two incentives are substitutive. Recognition can be an alternative for a company to motivate its employees to produce a more creative performance. Second, even though the directive leadership style is more effective in some performance contexts (Lorinkova et al., 2013; Yun et al., 2005), in the context of creative performance, empowering leadership can actually produce a creative performance that is higher than directive leadership can. This is because the organization's position does not strongly influence the generation of ideas, but rather the organization's belief is that its employees can be creative. Therefore, it encourages employees to think more creatively.

Practically, the results of this study are expected to provide knowledge to companies that they can use tournament incentives or recognition incentives to encourage creative performance. In addition, company leaders can also be inspired to apply leadership styles that are able to stimulate creative performance, so that employees are able to produce a better performance.

Similar to other studies, this study also has several limitations which provide opportunities for further research. First, the cases and research procedures in this experiment were designed and carried out in the form of simplified illustrations of real conditions in the field. Creative performances in the real context typically tend to be more complex. Case manipulation applied in this study may have different results on the other cases. The next researcher can use the context of other creative performances to strengthen the results of this study. Second, this study only examined two types of incentives, namely tournament incentives (monetary) and recognition incentives (non-monetary). There are some other types of incentives that have not been studied, so they are opportunities for further research. Third, this study did not investigate individual factors such as the differences in the participants' cognitive styles. There are two cognitive styles namely adaptive and innovative cognitive styles. Both cognitive styles may have an impact on the resulting creative performance. Fourth, the results of this study indicate that the increase in creative performance is greater with incentives that contain intrinsic motivation rather than with incentives that are only an extrinsic motivation. Researchers do not use feedback incentives because these incentives have no effect on Lourenco's (2016) research. This research has a different context with the research conducted by Lourenco (2016), so that feedback can influence creative performance because feedback can produce motivated employees. Fifth, the participants in this study were students, so it was possible there were differences from the real-life context. Therefore, further research could use managers as the control groups in order to produce more robust research and results. 


\section{Acknowledgement (if any)}

This research was fully supported by Lembaga Pengelola Dana Pendidikan (LPDP), Ministry of Finance, Indonesia.

\section{REFERENCE}

Alge, B. J., Ballinger, G. A., Tangirala, S., \& Oakley, J. L. (2006). Information privacy in organizations: Empowering creative and extra role performance. Journal of applied psychology, 91(1), 221.

Amabile, T. (1996). Creativity and innovation in organizations [Harvard Business School Background Note (pp. 396-239)]. Boston: Harvard Business School.

Amabile, T. M., Schatzel, E. A., Moneta, G. B., \& Kramer, S. J. (2004). Leader behaviors and the work environment for creativity: perceived leader Support. The Leadership Quarterly, 15, 5-32.

https://doi.org/10.1016/j.leaqua.2003.12.003

Amabile, T. M., Conti, R., Coon, H., Lazenby, J., \& Herron, M. (1996). Assessing the work environment for creativity. Academy of management journal, 39(5), 1154-1184.

Backes-Gellner, U., \& Pull, K. (2013). Tournament compensation systems, employee heterogeneity, and firm performance. Human Resource Management, 52(3), 375398.

Benazir, \& Iqbal, N. (2015). Impact of rewards and leadership on the employee engagement in conventional banking sector of Southern Punjab impact of rewards and leadership on the employee engagement in conventional banking sector of Southern Punjab Benazir, Dr Nadeem Iqbal. International Letters of Social and Humanistic Sciences, 57, 30-34. https://doi.org/10.18052/www.scipress.com/ ILSHS.57.30

Bonner, S. E., \& Sprinkle, G. B. (2002). The effects of monetary incentives on effort and task performance: theories, evidence, and a framework for research. Accounting, Organizations and Society, 27, 303-345.
Bowen, D. E., \& Ostroff, C. (2004). Understanding HRM-Firm performance linkages: the role of the "strenght" of the HRM system. Academy of Management Review, 29, 203-221.

Cadsby, C. B., Engle-Warnick, J., Fang, T., \& Song, F. (2015). Psychological incentives, financial incentives, and risk attitudes in tournaments: An artefactual field experiment.

Charness, G., \& Grieco, D. (2018). Creativity and incentives. Journal of the European Economic Association, 0, 1-43. https://doi.org/10.1093/jeea/jvx055

Chen, M. Y., Lin, C. Y., Lin, H., \& Iii, E. F. M. (2012). Does transformational leadership facilitate technological innovation? the moderating roles of innovative culture and incentive compensation, 239-264. https://doi.org/10.1007/s10490-012-9285-9

Chen, Williamson, M. G., \& Zhou, F. H. (2012). reward system design and group creativity: an experimental investigation. The Accounting Review, 87, 1885-1911. https://doi.org/10.2308/accr-50232

Cools, M., Stouthuysen, K., \& Abbeele, A. Van den. (2017). Management control for stimulating different types of creativity: the role of budgets. Journal of Management Research, 29, 1-21.

Cooper, Do. R., \& Schindler, P. S. (2014). Business Research Methods (12th ed.). McGraw-Hill Irwin.

Davila, A., \& Ditillo, A. (2017). Management control systems and creativity. Oxford Handbook of Strategy Implementation, 393. Online.

https://doi.org/10.1093/oxfordhb/978019065 0230.013.24

Delfgaauw, J., Dur, R., Sol, J., \& Verbeke, W. (2013). Tournament incentives in the field: Gender differences in the workplace. Journal of Labor Economics, 31(2), 305326.

Eisenberger, \& Cameron, J. (1998). Reward, intrinsic interest, and creativity: New 
findings. American Psychologist, 53, 676679.

Erat, S., \& Gneezy, U. (2016). Incentives for creativity. Experimental Economics, 19(2), 269-280.

Friedman, R. S., \& Förster, J. (2001). The effects of promotion and prevention cues on creativity. Journal of personality and social psychology, 81(6), 1001.

Gong, Y., Zhou, J., \& Chang, S. (2013). Core knowledge employee creativity and firm performance: The moderating role of riskiness orientation, firm size, and realized absorptive capacity. Personnel Psychology, 66(2), 443-482. https://doi.org/10.1111/peps.12024

Hammermann, A., \& Mohnen, A. (2014). The pric (z) e of hard work: Different incentive effects of non-monetary and monetary prizes. Journal of economic psychology, 43, 1-15.

https://doi.org/10.1016/j.joep.2014.04.003

Hennessey, B. A., \& Amabile, T. M. (2010). Creativity. Annual Review of Psychology, 569-598.

https://doi.org/10.1146/annurev.psych.0930 08.100416

Huo, K. (2016, August). The Effects of Performance Incentives and Creativity Training on Creative Problem-Solving Performance. AAA.

Iyer, B., \& Davenport, T. H. (2008). Reverse engineering Google's innovation machine. Harvard Business Review, 86(4), 58-68.

Jung, D. I. (2001). Transformational and transactional leadership and their effects on creativity in groups. Creativity Research Journal, 13(2), 185-195. https://doi.org/10.1207/S15326934CRJ1302

Kachelmeier, S. J., Reichert, B. E., \& Williamson, M. G. (2008). Measuring and motivating quantity, creativity, or both. Journal of Accounting Research, 46(2), 341-373.

Kanter, R. M. (1982). Dilemmas of managing participation. Organizational Dynamic, 11,
$5-27$.

Kim, H., Sutton, K. L., \& Gong, Y. (2013). Group-based pay-for-performance plans and firm performance: the moderating role of empowerment practices. Asia Pacific Journal of Management, 30, 31-52. https://doi.org/10.1007/s10490-011-9255-7

Klotz, A. C., Wheeler, A. R., Halbesleben, J. R. B., Brock, M. E., \& Buckley, M. R. (2012). Can reward systems influence the creative individual? In Handbook of Organizational Creativity (pp. 607-632). Elsevier Inc. https://doi.org/10.1016/B978-0-12-3747143.00024-0

Kosfeld, M., \& Neckermann, S. (2010). getting more work for nothing? symbolic awards and worker performance (IZA Discussion Papers No. 5040).

Kuenzi, M., \& Schminke, M. (2009). Assembling fragments into a lens: A review, critique, and proposed research agenda for the organizational work climate literature. Journal of management, 35(3), 634-717. https://doi.org/10.1177/0149206308330559

Lorinkova, N. M., Pearsall, M. J., \& Sims Jr, H. P. (2013). Examining the differential longitudinal performance of directive versus empowering leadership in teams. Academy of Management Journal, 56(2), 573-596.

Lourenço, S. M. (2016). Monetary incentives, feedback, and recognition-Complements or substitutes? Evidence from a field experiment in a retail services company. The Accounting Review, 91(1), 279-297. https://doi.org/10.2308/accr-51148

Martin, S. L., Liao, H., \& Campbell, E. M. (2013). Directive versus empowering leadership: A field experiment comparing impacts on task proficiency and proactivity. Academy of Management Journal, 56(5), 1372-1395.

McLean, L. D. (2005). Organizational culture's influence on creativity and innovation: a review of the literature and implications for human resource development. Advances in developing human resources, 7(2), 226-246. 
Mehta, R., Dahl, D. W., \& Zhu, R. J. (2017). Social-recognition versus financial incentives? Exploring the effects of creativitycontingent external rewards on creative performance. Journal of Consumer Research, 44(3), 536-553. https://doi.org/10.1093/jcr/ucx062

Morse, G. (2006). Sparking creativity at Ferrari. Harvard Business Review, (April).

Mubarak, F., \& Noor, A. (2018). Effect of authentic leadership on employee creativity in project-based organizations with the mediating roles of work engagement and psychological empowerment. Cogent Business \& Management, 5(1), 1429348.

Shalley, C. E., \& Gilson, L. L. (2004). What leaders need to know: A review of social and contextual factors that can foster or hinder creativity. The leadership quarterly, 15(1), 33-53.

Shalley, C. E., Zhou, J., \& Oldham, G. R. (2004). The effects of personal and contextual characteristics on creativity: Where should we go from here? Journal of management, 30(6), 933-958.

Sims, H. P., Faraj, S., \& Yun, S. (2009). When should a leader be directive or empowering? how to develop your own situational theory of leadership. Business Horizons, 52, 149 158.

https://doi.org/10.1016/j.bushor.2008.10.002

Skinner, B. F. (1938). The behavior of organisms: an experimental analysis. AppletonCentury.

Speckbacher, G. (2017). Creativity research in management accounting: A commentary.
Journal of Management Accounting Research, 29(3), 49-54. https://doi.org/10.2308/jmar-51754

Stajkovic, A. D., \& Luthans, F. (2001). Differential effects of incentive motivators on work performance. Academy of management journal, 44(3), 580-590.

Takatsu, S. (1984). Organizational equilibrium under uncertainty. Kybernetes, 13, 87-92.

Takeuchi, R., Lepak, D. P., Takeuchi, R., Lepak, D. P., \& Wang, H. (2007). An empirical examination of the mechanisms mediating between high-performance work systems and the performance of Japanese. Journal of Applied Psychology, 92, 1069-1083. https://doi.org/10.1037/00219010.92.4.1069

Thompson, G., \& Vecchio, R. P. (2009). Situational leadership theory: a test of three versions. The Leadership Quarterly, 20, 837-848.

https://doi.org/10.1016/j.leaqua.2009.06.014

Vroom. (1964). Work and motivation. New York: Wiley.

Yun, S., Faraj, S., \& Sims Jr, H. P. (2005). Contingent leadership and effectiveness of trauma resuscitation teams. Journal of Applied Psychology, 90(6), 1288. https://doi.org/10.1037/00219010.90.6.1288

Zhang, X., \& Bartol, K. M. (2010). Linking empowering leadership and employee creativity: The influence of psychological empowerment, intrinsic motivation, and creative process engagement. Academy of management journal, 53(1), 107-128. 